\title{
ENSINO DE HISTÓRIA E SENSIBILIDADE: O VER, O OUVIR E O IMAGINAR NAS AULAS DE HISTÓRIA
}

\author{
HISTORY TEACHING AND SENSITIVITY: \\ SEEING, HEARING AND IMAGINING IN HISTORY CLASSES
}

Azemar dos Santos Soares Júnior ${ }^{1}$

\begin{abstract}
RESUMO: Esse artigo tem por objetivo pensar a aula de História do Ensino Básico a partir das sensibilidades, daquilo que nos passa, que nos toca, que nos forma a partir daquilo que sentimos. Um debate que gira em torno do "fazer sentido" da História para os alunos. Metodologicamente, utilizo relatos de experiência docente para problematizar as sensibilidades nas aulas de História. Dessa forma, os conceitos de sensibilidade e experiência, postulados, respectivamente, por Sandra Pesavento (2007) e Jorge Larrosa (2016) são importantes para pensar um Ensino de História liberto da malha asfixiante do modelo tradicional de ensino. Conclui-se que faz-se cada vez mais necessário a utilização de modelos de ensino capazes de permitir formar cidadãos através da sensibilidade, da criatividade, do ver, do ouvir e imaginar. Alunos comprometidos com sua realidade social, que assumem sua identidade e respeitam a alteridade.
\end{abstract}

Palavras-chave: Ensino de História, sensibilidade, experiência, criatividade.

ABSTRACT: This article aims to reflect on the history classes in basic education stemming from the sensitivities, from what happens to us, what touches us, what shapes us from what we feel. A debate that revolves around "making sense" of history for students. Methodologically, I use reports of teaching experience to problematize sensitivities in History class. Thus, the concepts of sensitivity and experience, postulated respectively by Sandra Pesavento (2007) and Jorge Larrosa (2016), are important to think of a History Teaching freed from the asphyxiating mesh of the traditional teaching model. In conclusion, it is becoming increasingly necessary to use teaching models capable of forming citizens through sensitivity, creativity, seeing, hearing and imagining. Students committed to their social reality, who assume their identity and respect alterity.

Key words: History Teaching, sensitivity, experience, creativity.

\footnotetext{
${ }^{1}$ Graduado em História (UEPB), mestre em História (UFPB) e doutor em Educação (UFPB). Atualmente é professor da área de Ensino de História, do Departamento de Práticas Educacionais e Currículo, da Universidade Federal do Rio Grande do Norte (DPEC/UFRN). Está vinculado ao Programa de Pós-Graduação em Educação, da Universidade Federal do Rio Grande do Norte (PPGEd/UFRN), e ao Programa de Pós-Graduação em História, da Universidade Federal de Campina Grande (PPGH/UFCG).
} 


\section{Introdução}

Viajar à lua. Talvez este seja o sonho de tantos homens e mulheres que se encantam com a beleza que dela emana. Não chamaria de lunático, aquele que deseja pisar no grande CD de luz que habita o céu. Pisar em solo lunar representa o desejo de sonhar, imaginar, utilizar a sensibilidade tão natural à subjetividade humana.

Tomo de empréstimo os escritos de Cyrano de Bergerac, em meados do século XVII, e intitulado "Viagem à lua", para pensar as sensibilidades nas aulas de História. Tal narrativa conta a história de um viajante que aspira chegar à lua. Ele acreditava que, na lua, os papéis se invertiam: lá existiriam seres humanos, animais, plantas; que a vida tinha ânimo; que durante a noite, a sua lua era o nosso planeta, a Terra. Um mundo imaginado em que o sol governava o dia, e terra (lua para eles) alumiava a noite. Imagens timbradas pelos artifícios da mente humana. Sonhos estampados naquele homem/viajante a bordar fantasias. Desejos lunáticos que despertaram o interesse de criar tecnologias lunáticas como ele.

Viajar à lua exigia técnica, façanhas, criatividade. Só tornar-se-ia realidade com a construção de uma máquina que conduzisse seu corpo até o outro mundo. Aquele mundo que, como um pirilampo, brilhava na noite dos terráqueos. Para isso, tratou de construir uma máquina feita de frascos carregados de orvalho. Uma espécie de roupa de garrafas. Uma roupa capaz de despertar susto nos habitantes da lua. Uma máquina que o levou ao mundo dos sonhos. O viajante, viajava à lua. Metáfora de uma tecnologia possível, das artes produzidas por seres humanos, do desenvolvimento do pensar, de uma Educação oferecida através da criatividade, da sensibilidade, da imaginação. Ir até a lua, para o viajante, representava encontrar uma outra sociedade, a concretização de um sonho. Ir à lua, por meio da imaginação, representa a possibilidade da construção de um novo saber, de outras/novas descobertas, de formas de ver, de ser e de ter. 
O viajante, encontrou na lua uma sociedade que vivia ao avesso do nosso mundo: os seres eram híbridos humanizados que andavam com quatro patas; o respeito era graça dada aos mais novos; o alimento que sustentava a vida estava nos odores; a vida só se findava por opção dos lunáticos; riqueza, ostentação eram sinônimos de desprezo, de desdém. Uma sociedade contrária às normas que regiam a vida humana na Terra. 0 viajante sugere, através da imaginação, a capacidade de incentivar a mudança, a reflexão, o pensar, o agir.

Posso afirmar que a imaginação surgiu com o ser humano. Por si só, esses já possuem a capacidade de perceber, de tirar suas conclusões. Soma-se a isso, a utilização dos recursos oferecidos pela natureza e o saber fazer aprendido com as práticas cotidianas ao longo do tempo. Foi assim que o ser humano passou a produzir e controlar o fogo; a timbrar com estiletes traços que evoluíram formando letras, palavras, frases, textos; papiros que ganharam outras texturas compondo livros; metais que após a prova do fogo receberam curvas, formas, poderes; pedras que lapidadas formaram prédios, monumentos. Máquinas que reivindicaram o lugar antes ocupado por seus criadores. Robótica que reduziu os espaços, viabilizou a circulação de saberes, promoveu o aumento da solidão. Educação tecnológica que gestou nativos digitais e normalizou imigrantes digitais. 0 que seria o mundo sem a imaginação? Como seria uma escola sem sonhos? Ou, uma aula de História sem sensibilidade?

O viajante a lua, nos sugere imaginar, que significa formular nossas formas de ver e perceber o mundo. Nossas idiossincrasias. Metáfora de uma atividade lúdica: fechar os olhos, nos reportarmos até o passado (ou até a lua?) e de lá construir nossas percepções, sensações e sensibilidades. É sobre essa tarefa que dedicarei essas linhas: pensar a aula de História do Ensino Básico a partir das sensibilidades, daquilo que nos passa, que nos toca, que nos forma a partir daquilo que sentimos. Metodologicamente, analiso nessas linhas as marcas da minha experiência em sala de aula, relatos vividos, sentidos, experienciados. Trata-se de uma pesquisaparticipante, não no sentido de um único caso, mas de diversas 
experiências ao longo de minha trajetória enquanto professor. Ou seja, os dados apresentados e analisados nesse texto foram selecionados a partir da minha atuação como docente no Ensino de História.

Para tanto, tomo de empréstimo os princípios do "cuidado de $\mathrm{si}^{\text {" }}$ proposto por Michel Foucault (2014) como "uma forma de vida", de sentir, de aprender, de cuidar de si. Aprendi, a partir desse princípio, a "desaprender" as formas dominantes de poder, bem como a travar um combate permanente em que 0 ato de ensinar História se personifica na necessidade de dar ao indivíduo - nossos alunos -, desejo e coragem para compreender a vida. Entendo que o Ensino de História precisa fazer sentido aos alunos que, a partir dos ensinamentos, ressignificam sua existência.

\section{Sensibilidade, imaginação e experiência no Ensino de História}

A aprendizagem passa por aquilo que nos toca, que nos faz sentir. Assim, o primeiro desafio de um professor de História, parece ser "atribuir sentido" para o aluno. Penso que cada vez menos tem importado quem descobriu o Brasil, quem proclamou a República, ou quem venceu a guerra, mas tem importância pensar o que esses atos significaram em termos de direitos adquiridos à sociedade, à importância de saber, conhecer e viver tais conquistas. Tem importado, cada vez mais, entender a História do meu aluno, de sua família, de sua rua, sua comunidade; os problemas que são vivenciados (e que nem sempre são diferentes dos nacionais ou globais); suas preocupações, medos, angústias, desejos e sonhos. Tem importado saber que, em um dia qualquer, alguém sonhou em libertar-se, por exemplo, da malha asfixiante da escravidão, da violência de lesa-corpo e lesa-alma, da dor de não ser cidadão, mas que encontrou em seus desejos forças para resistir e lutar por uma sociedade mais justa. Tem feito sentido entender que não existe normal ou anormal, apenas diferenças. Que brancos, pretos, pobres, indígenas, gays, gordos, deficientes, são cidadãos e precisam gozar do merecimento conquistado de ir e vir. Que a História só 
faz sentido quando nós, professores, nos permitimos criar uma roupa de garrafas cheias de orvalho capaz de conduzir nossos alunos até o passado, e, de lá, construir nossas próprias percepções, sensações, "verdades".

Repito: "fazer sentido" talvez seja o grande desafio. Requer combater as aulas enfadonhas, pautadas na repetição de histórias contadas e não imaginadas. Exige lutar contra as velhas práticas de perguntas e respostas, ou de que o livro didático é a única fonte possível der ser utilizada em sala de aula. Que cabe ao nosso aluno aprender apenas aquilo que está publicado nas páginas do livro, ou escrito no quadro negro, como uma verdade absoluta e inquestionável. Requer romper com uma prática, que apesar do intenso combate dos docentes nas universidades, parece ainda reinar de forma soberana. Requer, como propõe Durval Muniz de Albuquerque Jr (2010) deformar o ensino: fazê-lo diferente, respeitar a alteridade, problematizar os sentimentos, atribuir outros sentidos à escola, exumá-la da repetição, do metodismo, da ausência de tesão, do lugar da obrigação. Solicita, com urgência, uma escola e uma aula de História desejada.

Fazer "fazer sentido" para o nosso aluno é encontrar num currículo, muitas vezes engessado, formas de burla, táticas diferenciadas de debate, exposição daquilo que se pensa. É perceber que, nós professores, competimos com uma indústria cada vez mais potente de produção de imaginação. É usar esses recursos a nosso favor. É, tomando os devidos cuidados, trazer uma cena qualquer do fenômeno que se tornou a série Game of Thrones ${ }^{2}$ e pensar, por exemplo, a partir da personagem de Daenerys Targaryan como montar num dragão e matar um exército inteiro, ou melhor, imaginar a partir dessa cena como líderes com sede de governar desejaram possuir tais poderes para destruir o inimigo; ou ainda, como uma mulher pode se sentir empoderada quando se fala de um lugar de poder:

\footnotetext{
2 Game of Thrones é um seriado da HBO criado como a adaptação dos livros escritos por George R. R. Martin, reunidos na série As Crônicas de Gelo e Fogo ( $A$ Song of Ice and Fire), composta por sete volumes, cinco dos quais já publicados. Suas histórias relatam intrigas, luta pelo poder, pelo amor, pela honra e pela fortuna, anseios que permeiam a vida os habitantes dos ficcionais Sete Reinos de Westeros, em um tempo inspirado na Idade Média e permeado de elementos sobrenaturais.
} 
em cima de uma máquina de matar, capaz de causar medo e obediência; pensar que tais lugares podem ser cobiçados por despertar desejo na sensualidade dos gestos. Imaginar a partir dessas cenas, como se vivia numa Europa feudal, o que comiam, como pensavam, como se vestiam... marcas de um cotidiano muitas vezes sucumbido pelo livro didático por achar mais interessante entender o poder de uma instituição num dado momento.

"Fazer sentido" é problematizar em sala de aula a música cantada por Mc Kevinho, batizada por "Olha a explosão" e que virou sucesso tocado nas plataformas digitais e visualizadas milhares de vezes na página do YouTube. É certo que a música não nos diz muita coisa além de tentar imaginar que "a novinha é terrorista, é especialista e o que ela faz no baile funk com as amigas", e claro, como "ela bate com a bunda no chão". Sucesso ouvido, cantado e dançado por nossos alunos. Cabe ao professor de História, a partir dessa realidade, chamar a atenção de fatos como: para que $M c$ Kevinho pudesse gravar essa música, historicamente toda uma geração de compositores e cantores sofreram em seus corpos a perseguição da moral cristã e dos militares que as defendiam com unhas e dentes, ou melhor, com prisões, exílios, violência e morte; que para ser "novinha, terrorista, especialista e descer com a bunda no chão", a mulher pode ser entendida como uma detentora de sedução por meio do seu corpo capaz de se contorcer, de um corpo que foi adestrado para despertar desejo, mas que também é um corpo que precisa ser respeitado. Que um corpo empoderado não dá aos outros o direito de subjugá-lo, de violentá-lo, de estuprá-lo.

E continuo afirmando, "fazer sentido" é possibilitar aos nossos alunos - além daqueles que já possuem -, o sonho de ser estrela, assim como deu Clarice Lispector a Macabea, retirante, pobre, alagoana, feia e dona de ovários murchos, mas que sonhava em ser estrela. Macabea não arrastou a bunda no chão, embora tenha pensado sobre suas colegas de quarto que explodiam até o chão; não montou num dragão que cuspia fogo e matava, embora tenha desejado, num dado momento, matar alguém; mas, sonhou 
em ser estrela. É certo que ela morreu sonhando, mas, antes disso, sua história denunciou os abusos de um dito "cabra-macho" sobre seu corpo; publicou nas páginas d'A hora da estrela a condição de uma mulher nordestina fora de sua geografia. Macabea era diferente: por isso causava estranhamento. Era esquisita, desinteressante. Era uma mulher ordinária, como descrita por Michel de Certeau (2008, p. 57): aquela que é uma "heroína comum", anônima, que "é o murmúrio das sociedades", que inventa o cotidiano de mil maneiras. Uma "personagem disseminada, caminhante, inumerável, invocando no limiar dos relatos o ausente que Ihes dá princípio e necessidade". Aquela que ocupa a cena. Aquela que não vem de famílias que possuem brasões. Que é muito mais figurante, como aqueles amontoados por todos os lados, que se fixa na multidão e que é devorada pelo anonimato. A mulher ordinária é aquela que, em seu cotidiano, reinventa a si própria ao invadir/tomar a propriedade, os bens materiais e imateriais de outros ${ }^{3}$. Era como uma pessoa qualquer, que dentro da nossa própria sala de aula, pode ser considerada diferente e por isso vítima de preconceito. O docente, nesse momento tem a oportunidade de convidar os alunos a uma boa prosa: imaginar como se sentia aquele que foi/é vítima de preconceito; trazer relatos de pessoas que passaram por essa situação e conduzir o discente à sensação, à percepção. Com pequenos gestos, a História pode começar a "fazer sentido" para nossos alunos. Metáfora de um ensino que (de)forma por meio da sensibilidade.

Fazer as aulas de História "fazerem sentido" para o aluno precisa ser um exercício contínuo do professor. Para isso, sensibilidade, imaginação e experiência são fundamentais. Essas são palavras que combinam com uma prática cotidiana. Palavras que sugerem pensar o indivíduo "através de suas reações íntimas, por suas contradições abertas ou encobertas [...] ela escava destinos, exuma afetos, mas sempre para reinseri-los em conjuntos significativos mais vastos" (GRUZISNKI, 2007, p. 07-08), ou seja, trazer à

\footnotetext{
3 Michel de Certeau (2008) define no original o termo "homem ordinário", abuso da licença poética para tratar no texto o termo no feminino: "mulher ordinária". Nesse sentido, nossos alunos, sobretudo aqueles de escola pública, são homens e mulheres ordinários, comuns, carentes de saber, de atenção, de vez e voz.
} 
tona aquilo que se sente, que se pensa e que tantas vezes fica apenas no interior dos corpos e mentes pela ausência de oportunidade de expor. Revelar a sensibilidade em sala de aula torna-se uma oportunidade de expressão, de autoafirmação, de comunicar o que sentimos ao outro, de deixar à mostra nossas fragilidades e, ao mesmo tempo, nossa fortaleza. Para Stuart Walton (2007) a sensibilidade é condição humana. Seu estudo, a partir do que postulou Charles Darwin em "Expressão das emoções nos homens e nos animais" (1872), anunciou a existência de emoções básicas que podiam ser interpretadas facilmente: felicidade, tristeza, raiva, medo, desgosto ou repulsa e surpresa - e acrescentou a essas seis, mais três: ciúme, vergonha e surpresa. Assim, defendeu que "as emoções não são apenas aqueles surtos espasmódicos de sentimento que surgem em resposta aos estímulos externos [...] elas são o alicerce sobre os quais repousa grande parte da nossa vida social e cultural" (WALTON, 2007, p. 20). As emoções são responsáveis por serem propulsoras da sensibilidade. Se elas são o alicerce da nossa vida, como nossa estrutura física faz-se necessário nos apropriarmos dela para entendermos a História e construirmos a nossa própria História.

Por vezes, acredito que a sensibilidade funciona como uma metáfora: dizemos uma coisa com nome de outra. Muitas vezes dizemos uma coisa e sentimos outra. Talvez em sala se aula o professor não esteja habituado a falar do sensível, pois acredita que a escola precisa ser árida, seus ventos radioativos, seus conteúdos intransmutáveis, sua disciplina adestradora. Gosto da proposta da metáfora para pensar as sensibilidades: por meio delas "dizemos que uma coisa é ou parece outra" (SONTAG, 2007, p. 01). Essa tarefa requer expressividade, criatividade, um pouco de retórica, a utilização de floreios. As metáforas são gestadas a partir da imaginação. Primeiro precisamos imaginar, para poder sentir e expressar através de metáforas.

Para Keith Jenkins (2009), a História repousa numa dada temporalidade que chamamos de passado. Assim, ao imaginar uma História 
contada, seja nos escritos de um historiador, seja na voz de um professor que dá aulas de História, se "reapresenta" um tempo, um passado. Devido aos métodos tradicionais de se ensinar, ainda tão comuns em sala de aula, os alunos acabam por esperar uma narrativa "verdadeira", fidedigna ao acontecido. Entendo que o real jamais será reconstruído como de fato aconteceu. O que fazemos ao escrever ou contar uma História é construir uma narrativa com "uma pretensão à 'verdade' e refere-se a um passado real" (PESAVENTO, 2003, p. 18). A imaginação se configura como um "ter sido, mas de forma problemática, por não ser mais observável nem passível de reexperimentação, ele é apenas imaginado" (PESAVENTO, 2003, p. 19).

Dessa forma, concordo com Paul Ricoeur (1997) ao falar sobre a ficcionalização da História. A imaginação histórica tornou-se a forma possível de o leitor e/ou aluno chegar metaforicamente ao passado, ao fato histórico. Para Sandra Pesavento (2003), embebida nos escritos de Ricoeur, o imaginário desempenha a função de "construir" imageticamente aquilo que vem a ser o passado, colocando-se no seu lugar e figurando como se fosse a realidade. Ora, com tais elementos fictícios, a História se aproximaria do tipo de construção de intriga presente na narrativa literária, mas construindo uma ilusão controlada, pelos traços ou fontes e pela pretensão de verdade.

Se o relato de um historiador, como aponta Keith Jenkins (2009), nunca corresponde exatamente ao passado e nenhum relato consegue recuperá-lo tal qual ele era, entendo que a História está fadada a ser um constructo pessoal, subjetivo. Que cada expectador das histórias ensinadas, entenda-se alunos, elaboram suas versões da História a partir de sua imaginação, da forma como se vê o mundo, do meio em que estão imersos, das experiências vividas, dos sentimentos cativados. Se o historiador, a partir das fontes dá nova feição à História, os alunos reelaboram imageticamente "aquilo que aconteceu". Ao seu modo.

É o que os poetas fazem: eles convivem com os sentimentos, com a imaginação, para depois, com um toque de retórica, timbrar em papel poesia qualificada. É o que os historiadores fazem: se debruçam sobre as 
fontes, fazem leituras delas. Convivem com as fontes. Aplicam sobre elas um método: contorcem-nas, ouvem seus sussurros, questionam. A partir delas imaginam o fato ocorrido, criam metáforas e transpõem para a escrita uma narrativa que acreditam assumir um compromisso com o real. É o que os professores de História fazem (ou deveriam fazer): a partir do conteúdo a ser discutido, selecionam seu material didático ${ }^{4}$, convivem com eles por um tempo, leva-os para sala de aula e, junto a seus alunos, tentam perceber as intencionalidades, as afetividades, os destinos alterados. É o momento da partilha de informações. É o momento que as sensibilidades afloram. Momento em que repousa sobre o material didático o olhar: imagina, percebe, sente. Nem sempre há a necessidade de construir um texto escrito ou uma atividade, mas há um compromisso com a formação do cidadão, com aquilo que está guardado na intimidade.

Permitir que as emoções aflorem nas aulas de História é possível através da capacidade de se colocar no lugar do outro, da diferença, sair da zona de conforto. É respeitar a diferença, defendida por Tomaz Tadeu da Silva (2000) como "aquilo que o outro é", ou seja, em oposição a sua identidade $^{5}$. Esse outro pode ocupar lugares e temporalidades mais distantes ou mesmo mais próximas. Dessa forma, aprender História na diferença torna-se "exigência da aprendizagem histórico-temporal [...] exigência para a construção de uma sociedade democrática, marcada por relações de alteridade" (SIMAN, 2015, p. 208). As experiências históricas

\footnotetext{
4 Os materiais didáticos são instrumentos de trabalho do professor e do aluno, suportes fundamentais na mediação entre o ensino e a aprendizagem. Livros didáticos, filmes, notícias de jornais e revistas, fotografias, pinturas, objetos, relatos orais, dentre outros, que podem ser utilizados nas aulas de História. Esses materiais didáticos podem ser divididos em dois grupos: os suportes informativos, ou seja, aqueles que foram produzidos para serem utilizados em sala de aula nas disciplinas escolares, e os documentos que correspondem ao grupo de signos visuais ou textuais que são produzidos numa perspectiva diferente dos saberes das disciplinas escolares, mas que posteriormente passam a ser utilizados com a finalidade didática (Cf. BITTENCOURT, 2009, p. 295-297).

5 De acordo com Tomaz Tadeu da Silva (2000) a diferença é um produto derivado da identidade. Assim, a identidade é a referência, é o ponto original relativamente ao qual se define a diferença. Isto reflete a tendência a tomar aquilo que somos como sendo a norma pela qual descrevemos ou avaliamos aquilo que não somos. Nesse caso, o outro - aquilo que não sou -, é a diferença.
} 
contadas em sala de aula passam pelo processo de subjetivação de crianças, jovens e adultos. Ao ser imaginada, uma dada situação passa a fazer sentido humano, portanto, apreendida.

Conforme anunciou Sandra Pesavento (2007) as sensibilidades não brotam do racional, mas das formas de apreensão do mundo, daquilo que se sente. Uma forma de ser e estar num dado lugar. A tradução do que se vê em sensações e emoções. Uma reação quase imediata dos sentidos afetados por fenômenos físicos ou psíquicos, uma vez em contato com a realidade. Uma alquimia que envolve corpo e espírito. A sensibilidade exige percepção enquanto atividade reflexiva. Assim, ao levar para sala de aula um documento, o professor realiza leituras orientando os alunos a refletir. A percepção é responsável por produzir e/ou ativar sentimentos bons ou ruins que estão no campo do sensível. Os sentimentos orientarão os alunos a desejarem ou a rejeitarem determinadas ações. Assim, o professor ao selecionar um documento e utilizar em sala de aula, deve imaginar as diversas afetividades que queira compartilhar e/ou problematizar: amor, dor, esperança, pavor, alegria, medo. As sensibilidades serão tocadas sempre após a leitura das fontes, momento em que se criam as representações por meio do imaginário. Vejamos o exemplo: Um professor de História do Ensino Médio selecionou alguns relatos para problematizar os campos de concentração que existiram na Europa durante a Segunda Guerra Mundial. Vejamos o relato abaixo:

Será que eu pressentia estar entrando no reino da merda? [...] Diante de mim apareceu pela primeira vez o espetáculo assustador das fileiras de prisioneiros cobertos de fezes, com desarranjo dos intestinos, ao "Scheisse-Kommando" onde eu assistia incrédulo, ao zelo dos SS, olhando sem nojo aparente, para presos que chapinhavam em rios de merda [...] um dos prisioneiros foi forçado a comer seus excrementos (BECKER, 2009, p. 424).

O horror e o pavor são sentimentos que serão convocados de imediato. Perceber essa narrativa em sala de aula significa imaginar corpos enfileirados, adoecidos, sujos ou até mesmo podres, perambulando como porcos esfomeados em sua pocilga cotidiana, zumbis tateando na podridão 
e sendo forçados às mais terríveis situações capazes de conduzir à degradação humana. Pode despertar, no leitor, emoções como a raiva sobre aqueles que, sem razão aparente, sem piedade, sem compaixão, obrigavam homens e mulheres ao lugar de animais que, antes de morrer, deveriam ser aproveitados, ao máximo, em condições de exploração, e submetidos a terríveis situações. O sentimento de nojo é outro que se faz presente: a merda está diretamente associada ao corpo como se juntos formassem um monumento pavoroso. A merda é aquilo que nos escapa. Aquilo que é podre, que fede, que é descartado na intimidade. Quando queremos desprezar alguma coisa associamos à merda. Metáfora daquilo que deve ser relegado aos mais profundos poços.

A leitura do documento, acompanhada do imaginar, produz o ver e o sentir, ativa as emoções e aflora a sensibilidade. Percebe, reflete e sente. Aprende por meio do sensível. Para João Francisco Duarte Jr (2000), o sensível é tudo aquilo que pode ser percebido pelos sentidos. Para esse autor, o saber sensível é inelutável, primitivo, fundador de todos os demais conhecimentos, por mais abstratos que estes sejam; um saber direto, corporal, anterior às representações simbólicas que permitem os nossos processos de raciocínio e reflexão. Assim sendo, os alunos possuem em seu corpo, em seu pensamento, em sua História a possibilidade de resgatar os saberes oriundos dos sentidos no processo de apreensão do mundo. Essa "educação estética", conforme Duarte Jr (2000) não se restringe à escola, integrando-se à vida numa Educação ampla dos sentidos, na qual o conhecimento inteligível é apenas uma parte de um todo maior, articulado que está ao saber sensível.

O documento produziu um sentido, criou uma realidade e funcionou como um mecanismo de subjetivação. A leitura a partir do sensível provocou aquilo que chamamos de experiência, de "fazer sentido", de dar sentido àquilo que somos e ao que nos acontece. Para Jorge Larrosa (2016), a experiência é aquilo que "nos passa, o que nos acontece, o que nos toca. Não o que se passa, não o que aconteceu, ou o que toca. A cada 
dia passam muita coisa, ao mesmo tempo, quase nada nos acontece". Assim, uma aula de História que não toca, que não acontece, que não faz sentido, não promove a experiência, não é imaginada, não é sensível.

Ainda, conforme Jorge Larrosa (2016, p. 25), vivenciar a experiência de que algo nos aconteça e que nos toque, requer atenção, reflexão. Sugere apurar os sentidos: cheirar, ver, tocar, ouvir, provar, com paciência. Valorizar os detalhes, dar leveza e ter delicadeza. Uma atividade que tem se tornado bastante escassa numa sociedade do imediatismo e do espetáculo. Dessa forma, o professor que vive atarefado, que passa cada vez mais tempo na escola e tem cada vez menos tempo, faz com que a experiência se torne ação cada vez mais rara.

É preciso chamar a atenção dos professores para o fato de que sensibilidade e experiência andam juntas, como um acordo íntimo. Não se vive o que não se sente, e vice-versa. Nossos alunos não viveram a História, mas precisam refletir sobre a História, passar pela experiência do imaginar, do sentir para construir sua própria História. É preciso fazer com que os alunos vivam a experiência de se posicionar sobre o mundo, que sirva para construir subjetividades treinadas para ver, sentir, pensar, imaginar, para formar sujeitos comprometidos com a sua comunidade, com os problemas de seu bairro, que aprenda a conviver com a alteridade, com as opiniões divergentes, com sensibilidade. É preciso fazer a História "fazer sentido".

A experiência do sentir e do imaginar passa pela disciplina do detalhe. Michel Foucault (2008, p. 120) escreveu sobre a "arte de talhar em pedras". Na ocasião, o autor se referia a arte dos detalhes que a disciplina sobre o corpo exigia alegando que todo detalhe era importante. O corpo era visto sob o olhar meticuloso, esmiuçante, sem que nada, um mínimo detalhe escapasse. A metáfora do detalhe oferece ao professor de História a lupa, responsável por ampliar aquele ponto antes relegado ao esquecimento, muitas vezes por ser considerado insignificante. Instrumento que representa a investigação, a busca por indícios. A arte do detalhe no Ensino de História, deve nos fazer parar para observar os pequenos rastros 
e refletir sobre os pontos antes relegados por sua ausência de importância. O detalhe no campo do sensível só poderá ser percebido se disciplinarmos o nosso olhar, se educarmos a tarefa de ver o que não foi dito, o que está escondido. Assim, retomo a contribuição de Sandra Pesavento (2007, p. 20) ao afirmar que só pelo esforço da imaginação, pela Educação e adestramento do olhar, recolhendo sinais, indícios, tecendo correlações, estabelecendo nexos entre as marcas deixadas, preenchendo lacunas e ausências, é que construiremos uma História que "faz sentido", pois disciplina o aluno a imaginar aquilo que não foi dito, a tirar suas próprias conclusões. Tarefa que exige dedicação, criatividade. Tarefa que não parece fácil, levando em consideração o cotidiano de professores desestimulados, a grande quantidade de aulas acumuladas semanalmente. Mediante esse quadro, proponho seguir na contramão do cotidiano escolar: eis a proposta para um Ensino de História sensível. Vencer o comodismo, lutar contra a mesmice, combater a repetição, evitar atividades de perguntas e respostas. Deve-se promover a emoção, incentivar a leitura, ofertar alimento à imaginação, tecer opiniões, autorizar a fala, sentir e deixar ser tocado.

É pensando a Educação do olhar para a arte do detalhe que parto para o último exemplo desse texto: o caso de Alexandrina Maria da Conceição. Façamos a leitura da notícia publicada por um jornal do final do século XIX:

[...] veio hontem ao nosso escritório queixar-se a retirante Alexandrina Maria da Conceição e contou-nos esta história, realmente triste: para aqui viera de Serra Redonda com sua família composta de marido, 4 filhos e uma sogra e por ordem do Sr. Gama Roza foram acomodados no sítio Cruz do Peixe. Bem ou ahi iam passando, graças a generosidade das cozinheiras do hospital e ao serviço que ao mesmo prestava seu marido. Com as chuvas que cahiam ultimamente, creou o seu marido Joaquim Barbosa da Silva a esperança de voltar para o seu torrão natal a ver-se a chuva permitia fazer-Ihe plantação e vir neste caso buscar sua família. Durante a ausência de Joaquim Barbosa é que sua família passa pelas torturas da fome e maus tratos do diretor do hospital o Sr. Major Francisco de Sá Pereira, a quem nos disse a queixosa suplicou muitas vezes de joelhos uma esmola para seus pobres filhinhos e sua velha sogra que morria de fome e tudo foi baldado. [...] num último pedido de desespero, ainda de 
joelhos, deu-lhe ele tão grande empurrão que ella rolou no chão.

A publicação foi feita no dia 05 de agosto de 1889, pelo jornal Gazeta da Parahyba, que circulou na capital paraibana durante os últimos anos do oitocentos. Poderíamos pensar que o jornal estava preocupado com os pobres retirantes que passavam fome, com as mulheres violentadas que se submetiam a fazer súplicas de joelho àqueles que poderiam ajudar. Mas não seria de todo verdadeiro. O jornal pouco estava preocupado com a situação da família de Alexandrina Maria da Conceição, mas em fazer a denúncia que serviria para acusar o governo. Era a oposição se apropriando de um fato cotidiano (pobres retirantes amontoados pelas ruas) para denunciar. Táticas do jogo político. Guerra entre o Partido Conservador e o Partido Liberal. Porém, apesar de solucionar o problema da fome dos retirantes, não fosse a intenção, a publicação possibilita ao professor de História problematizar a condição dos pobres, pedintes, retirantes. Autoriza imaginar uma mulher de joelhos, vestida como maltrapilha a implorar comida para seus filhos e sua velha sogra. Permite sentir, por meio da imaginação histórica, as razões que levaram Alexandrina à referida ação, bem como a sentir a dor da queda após o empurrão, e a se enfurecer com a atitude do diretor do hospital em violentá-la. Permite se compadecer e se irritar, a não desejar vivenciar situações do tipo. Afetividades que podem ser sentidas quando a ação de imaginar, de utilizar a sensibilidade, tornam-se uma prática nas aulas de História.

Seja qual for a fonte histórica utilizada em sala de aula pelo professor, é possível pensar nos mais diversos segmentos de atuação do professor de História (Isso inclui os pedagogos que dão aulas de História6 na Educação Infantil, nas séries iniciais e na Educação de Jovens e Adultos do Ensino Fundamental). Essa notícia de jornal pode ganhar outros formatos, novas texturas. Ao levá-la às turmas do Ensino Fundamental, o docente pode ressignificar a fonte adequando-a à linguagem dos alunos. A

\footnotetext{
6 Optei por utilizar aqui o termo "professores que dão aula de História" no sentido de contemplar também os pedagogos que também ministram aulas de História nos diversos segmentos do Ensino Básico.
} 
História de Alexandrina pode ganhar outros contornos: através da contação de histórias, por meio da reescrita de sua História por parte dos discentes, pela comparação com histórias de pessoas conhecidas dos alunos - muitas vezes em suas próprias famílias, vizinhos, ruas, bairro -; a construção de outras representações, seja através de desenhos, ou mesmo, na utilização de meios digitais para reescrever/problematizar a História de tantas Alexandrinas.

Com tão pouco, a aula de História torna-se uma oficina de saberes e experiências. Imaginar, pensar, sentir, reescrever, reconstruir, produzir histórias a partir da fonte histórica levada para a sala de aula faz do aluno protagonista e a aula de História interessante. A partir do momento em que o professor seleciona uma fonte histórica, realiza a leitura e a problematiza em sala de aula, autoriza-se o discente a reconstruir o fato histórico a partir de sua experiência. Dessa forma, todos se tornam protagonistas. O aluno é valorizado duplamente: primeiro, por produzir a partir da fonte histórica um material didático; segundo, por ver o material didático que produziu ser problematizado em sala de aula.

\section{Criatividade nas aulas de História}

Numa aula de História do sexto ano do Ensino Fundamental, foi solicitado que os alunos se olhassem no espelho por alguns instantes. Após o período de observação da imagem de si, foi pedido que os alunos desenhassem numa folha em branco aquilo que tinham visto no espelho. Cada aluno desenhou sua autoimagem. Traços muitas vezes tortos, grotescos ou mesmo delicados. Todos com adereços, cabelos, roupas. Marcas de sua subjetividade transpostas pelos riscos. Os discentes desenhavam o que viram a partir da imagem que possuíam de si. Era a 
primeira aula no ano letivo. Momento propício para conhecerem uns aos outros, e para o professor perceber o perfil dos discentes, entender como eles se imaginavam, ouvir suas histórias individuais.

Após a confecção dos desenhos, os alunos foram reunidos em grupos de três para partilharem, entre si, suas imagens e suas histórias. Passado o tempo determinado para a atividade, iniciou-se a apresentação e debate. Um fato chamou a atenção: um grupo de meninas, no instante da exposição de suas imagens, anunciou que se viam como princesas. Eram três princesas: "Duas lindas e uma bonitinha", anunciou uma delas. Ao ouvir o relato, foi interpelado ao grupo sobre o porquê de haver duas princesas lindas e uma bonitinha7. O silêncio imperou. A professora percebeu que uma das três alunas era negra, portanto a bonitinha. A atividade proposta revelava, além de aspectos da identidade e da História dos alunos, preconceitos historicamente construídos fora da sala de aula. A tarefa fez surgir uma missão para a professora: discutir sobre diferença em sala de aula.

Iniciar o debate sobre o referido tema exigia preparação, por parte da professora. Ser conhecedora do assunto e responsável pela execução da Lei $10.639 / 2003^{8}$, de forma a seduzir os alunos, configurava-se como uma tarefa que exigiria criatividade, paciência e sensibilidade. Logo tratou de selecionar fontes históricas para realizar atividades em sala de aula que pudessem sugerir debate sobre o tema da diferença. Numa sequência didática responsável por dialogar com o conteúdo a ser ministrado, a professora realizou uma oficina de máscaras africanas, utilizou-se de jogos teatrais com uso de fantoches negros, fez leitura e debate de textos da literatura africana e de combate ao preconceito, reconstruiu em sala de aula situações de resistência, aprendeu a dançar capoeira. A resposta por parte

\footnotetext{
7 Esse relato pode ser consultado no trabalho de conclusão de curso de Maria da Conceição Freitas Braga, intitulado "Ela e eu temos o mesmo nome, mas somos bastante diferentes: construção da identidade negra no Núcleo de Educação da Infância", defendido em 2017.

8 A Lei 10.639/03 propõe novas diretrizes curriculares para o estudo da História e cultura afro-brasileira e africana. Por exemplo, os professores devem ressaltar em sala de aula a cultura afro-brasileira como constituinte e formadora da sociedade brasileira, na qual os negros são considerados como sujeitos históricos, valorizando-se, portanto, o pensamento e as ideias de importantes intelectuais negros brasileiros, a cultura (música, culinária, dança) e as religiões de matrizes africanas (Cf. CARVALHO, 2017).
} 
dos alunos veio de imediato: o interesse em conhecer mais sobre a cultura africana, sobre o respeito e a diferença.

Alguns fatos se sobressaem na narrativa e merecem destaque: o primeiro diz respeito à oportunidade aproveitada pela professora para discutir o tema, pois sabemos que, na maioria das vezes, situações como esta são corriqueiras em sala de aula, e os docentes acabam por negligenciar, por deixar passar, por não dar a devida importância; segundo, não foi preciso parar o conteúdo para tratar o assunto, pois como conhecedora da Lei 10.639/03, tratou de estabelecer os diálogos a partir do conteúdo que estava sendo ministrado; o terceiro aspecto está no campo da sensibilidade, por parte da professora, em ter dado a devida atenção à problemática, bem como por suscitar a imaginação e a capacidade dos discentes de se colocarem no lugar do outro ao problematizar, em sala, relatos de violência contra negros escravizados no período colonial e imperial brasileiro, relatos de resistência e de situações de preconceito que ainda acontecem no cotidiano dessas pessoas; o quarto e último aspecto, está na multiplicidade de fontes históricas problematizadas de forma sensível.

Atitude como essa requer criatividade. Sabemos que a criatividade se configura enquanto a capacidade de criar, inventar, construir, de não repetir, de surpreender, de ser autêntico, original. Como já afirmei, tarefa bastante difícil, porém fundamental. Uma aula criativa é capaz de prender a atenção do aluno, leva-lo a imaginar, a sentir, a viver, a experiência do aprender com o sorriso nos lábios, de rejeitar aquilo que não é bom, de respeitar a alteridade, de tornar-se cidadão conhecedor dos problemas sociais de sua rua, de seu bairro, de sua cidade. Uma aula criativa, leva à invenção de outras histórias, conduz o aluno ao lugar de criador, de protagonista de sua própria História.

Uma aula criativa, como defende Leandro Karnal (2016), pode incluir canais de comunicação, sensações, experiências e outros campos variados que aumentem o impacto da informação sobre o cérebro. Esta é a primeira 
virtude da criatividade: ela facilita a comunicação porque trabalha com o inesperado e, assim, ganha uma atenção mais focada. Faz com que os alunos entendam a construção de um conceito se ele for construído em sala de aula por meio de atividade lúdica, pela experiência individual, pelo debate coletivo.

Para que uma aula seja criativa, nem sempre se faz necessária a utilização de aparatos tecnológicos avançados - embora essa tecnologia contribua significativamente para esse processo, especialmente na era dos nativos digitais. Mas, levando em consideração a realidade das escolas públicas brasileiras, que nem sempre dispõem desse aparato, o diferencial deve partir de ideias criativas que considerem o espaço para realização, os recursos didáticos disponíveis, as fontes históricas que podem ser levadas para sala de aula, a linguagem adequada para os alunos e, acima de tudo, o compromisso docente com a formação de seus alunos.

Os jogos aparecem como uma das ferramentas bastante utilizadas na hora de inovar nas aulas de História. A confecção de dados históricos, de baú de memórias, de caça ao tesouro ou, até mesmo, jogos de perguntas e respostas que não valorizem apenas a memorização, são os mais desejados pelos discentes. A utilização de jogos privilegia o desafio, faz construir um vencedor - fato que incentiva o desejo de ganhar -, na mesma medida em que gera a colaboração por ser realizado, muitas vezes, em grupos. De acordo com Eucídio Pimenta Arruda (2014), os alunos passam por várias etapas de aprendizado quando participam de simulações: primeiro concentram-se nas regras do jogo e, quando têm acumulado competência básica nessa área, são capazes de aprender com o jogo, não sobre o jogo.

Apresentados como uma, dentre tantas, possibilidades de criatividade, o jogo não envolve apenas o lúdico, mas o desejo de competir, de participar, a interação entre os discentes, as estruturas políticas, as relações de poder, a comunicação, as diversas capacidades. Nem sempre os jogos manuais ou virtuais estão relacionados diretamente com a produção historiográfica e com os livros didáticos, daí a necessidade da orientação e intervenção do professor ofertando as devidas proporções. 
Perceba que o uso da criatividade para discutir determinados conteúdos em sala de aula, pode ser uma estratégia utilizada pelo professor em tarefas como romper preconceitos, desconstruir imagens historicamente engessadas pelo machismo, ou mesmo a ideia de que a coisa pública não precisa ser preservada, dentre outras. Assim, recorro à proposta de Michel Foucault (2014) para pensar o "cuidado de si", enquanto uma prática constante, um exercício cotidiano e para toda a vida. Entendo que a aula de História contribui decisivamente para esse cuidado de si, especialmente através das três funções postuladas pelo autor: a função crítica, responsável por levar o indivíduo a se desfazer dos maus hábitos, de opiniões falsas que podem vir de pessoas comuns, de professores desatualizados, de parentes, vizinhos, etc.; a função de luta, caracterizada por um combate permanente, formando não apenas um homem de valor, mas dando-Ihes as armas e a coragem que lhes permitirão defender a promoção da vida; e, por fim, a função pedagógica, como aquela que deve ensinar, através do que aconteceu, dos erros passados que não devem ser cometidos e, sobretudo, do cuidado com a alma.

Essas funções podem ser pensadas como metáfora para o Ensino de História: combater os maus hábitos significa romper com estigmas historicamente construídos e adicionados à Educação familiar, da rua; posicionar-se, ser protagonista, utilizar a voz para dizer o que sente e o que acredita, contribuindo, assim, para a formação de um cidadão consciente de si e responsável pela reorganização de uma sociedade mais justa. Uma Educação que também Ihe autoriza o uso das armas do respeito, da alteridade, da seriedade, da alegria de ajudar ao próximo, da cidadania e da democracia, do combate à corrupção e ao fascismo. Não um Ensino de História que funciona apenas por exemplificar os erros cometidos no passado e que devem ser evitados no presente, mas um ensino que se preocupe com a alma, metáfora do abstrato, das formas de pensar, de se posicionar, de elaborar as emoções, de fazer escolhas, de criar e de levar 
adiante para si e para os outros as diversas formas de arquitetar a bondade e a justiça.

Os pequenos gestos, que passam pela atividade de imaginar, ver e sentir, tornam-se cada vez mais fundamentais no processo de ensino e de aprendizagem dos discentes nas aulas de História. O Ensino de História anseia por ser desejado. Para tanto, clama por hábeis mãos criativas por parte dos docentes. Convoca os professores que dão aula de História a praticar e divulgar o "cuidado de si", o constante cuidado de si e do outro.

\section{Considerações finais}

Afirmar que sensibilidade, imaginação, experiência e criatividade são elementos fundamentais na atuação do professor de História, foi o que tentei esboçar nessas linhas. Precisamos atribuir sentido à História para nossos alunos que estão cada vez menos interessados em saber quem descobriu o Brasil ou quem o governou num dado momento. Dar sentido às aulas de História passa pela atividade de levar fontes históricas para a sala de aula, fazer leituras, imaginar as cenas, sentir as emoções vividas, deixar ser tocado pela experiência. Um desafio necessário.

Passa pela necessidade de pensar o "cuidado de si", aquilo que se aprende e o que se quer para a vida. Passa pela experiência que cada aluno traz consigo, aquilo que foi aprendido dentro de casa, nos recônditos do privado, ou mesmo na rua, nas brincadeiras, nas cenas do cotidiano, nas páginas da internet, nos programas de televisão ou nos aplicativos de comunicação. Aprender com a História é como alertou Michel Foucault (2014): um constante exercício de respeito consigo e com o outro. Uma forma de protagonizar a História que se quer construir para sua vida e para sua cidade. Um munir-se das armas corretas, sobretudo num tempo em que o fascismo veste sua mais sedutora indumentária para corromper os direitos historicamente conquistados através das lutas travadas pelas ditas minorias. 
Portanto, formar cidadãos, me parece estar para além da forma tradicional com que a disciplina vem sendo conduzida nas escolas Brasil afora. É extremamente comum chegar numa escola de Ensino Básico e se deparar com a realidade de professores que fazem das aulas de História, atividades de perguntas e respostas impressas nas páginas dos livros didáticos ou mesmo de seus resumos sem fins. Formar cidadão é assumir o compromisso com a criatividade, com a realidade dos discentes, com a alteridade, com a sensibilidade. É oferecer imaginação. É construir os conceitos que tornar-se-ão fundamentais para a vida em comunidade. É colocar em cheque a ideia de uma História única e propor a reescrita, ou melhor, a escrita de uma nova História, a partir do que se sente, das diversas formas de ver o mundo, de combater o fascismo e as formas de dominação.

Nós, professores de História, precisamos disciplinar nosso olhar. Precisamos usar a imaginação. Precisamos nos permitir sonhar. Sei que a cada dia a realidade das escolas tem varrido com ventos radioativos as nossas esperanças; mas não é hora de esmorecer. Ao contrário. É hora de permitir que a experiência do sentir torne-se ação cotidiana. Que a intimidade nos seja desnudada. Que tenhamos sensualidade nas aulas de História. É preciso olhar o outro com dignidade e fazê-lo perceber-se enquanto sujeito ativo responsável por alterar sua realidade social. Para tanto, sugiro viajarmos até lua. De lá [quem sabe?] veremos a Terra com outros olhos.

\section{Referências}

ALBUQUERQUE JÚNIOR, Durval Muniz de. Por um ensino que deforme: o docente na pós-modernidade. Disponível em: www.cnslpb.com.br/arquivosdoc/MATPROF.pdf. Acesso em: 02 fev. 2018.

ARRUDA, Eucidio Pimenta. Aprender história com jogos digitais em rede: possibilidades e desafios para professores. In: MAGALHÃES, Marcelo (Org.). 
Ensino de História: usos do passado, memória e mídia. Rio de Janeiro: FGV, 2014, p. 239-254.

BECKER, Anette. Extermínios. O corpo e os campos de concentração. In: COURTINE, Jean-Jacques (Org). História do corpo. As mutações do olhar. O século XX. Petrópolis: Vozes, 2009, p. 417-444.

BITTENCOURT, Circe Maria Fernandes. Ensino de História. Fundamentos e métodos. São Paulo: Cortez, 2009.

BRAGA, Maria da Conceição Freitas. "Eu e ela temos o mesmo nome, mas somos bem diferentes": construção da identidade negra no Núcleo de Educação da Infância. 2017. 32 f. Relato de Experiência (Graduação em Pedagogia) - Universidade Federal do Rio Grande do Norte, Natal, 2017.

CARVALHO, Leandro. Lei 10.639 e o ensino de história e cultura afrobrasileira e africana. Canal do Educador. Disponível em:

http://educador.brasilescola.uol.com.br/estrategias-ensino/lei-10639-03ensino-historia-cultura-afro-brasileira-africana.htm.

CERTEAU, Michel de. A invenção do cotidiano. Artes de fazer. Petrópolis: Vozes, 2008.

DUARTE JR, João Francisco. O sentido dos sentidos: a educação (do) sensível. Curitiba: Criar, 2001.

FOUCAULT, Michel. Vigiar e punir. História da violência nas prisões.

Petrópolis: Vozes, 2008.

Ditos e escritos IX. Michel Foucault e a genealogia da ética, subjetividade e sexualidade. Rio de Janeiro: Forense, 2014.

FONSECA, Selva Guimarães. Didática e Ensino de História. Rio de Janeiro: Papirus, 2008.

GAZETA DA PARAÍBA. Providências Sr. Dr. Gama Roza. 05 ago. 1889.

GRUZINSKI, Serge. Por uma história das sensibilidades. PESANVENTO, Sandra Jatahy; LANGUE, Frádérique. Sensibilidade na história: memórias singulares e identidades sociais. Porto Alegre: UFRGS, 2007, p. 7-8.

JENKINS, Keith. A história repensada. São Paulo: Contexto, 2009.

KARNAL, Leandro. Conversas com um jovem professor. Rio de Janeiro: Contexto, 2016. 
LARROSA, Jorge. Tremores. Escritos sobre experiência. Belo Horizonte: Autêntica, 2016.

PESAVENTO, Sandra Jatahy. Sensibilidades: escrita e leitura da alma. In: PESANVENTO, Sandra Jatahy; LANGUE, Frádérique. Sensibilidade na história: memórias singulares e identidades sociais. Porto Alegre: UFRGS, 2007, p. 9-22.

RICOEUR, Paul. Tempo e narrativa. Campinas: Papirus, 1997.

SILVA, Tomaz Tadeu da. A produção social da identidade e da diferença. In: Identidade e diferença. Rio de Janeiro: Vozes, 2000, p. 73-102.

SIMAN, Lana Mara de Castro. Aprender a pensar historicamente: entre cognição e sensibilidade. In: ROCHA, Helenice; MAALHÃES, Marcelo; GONTIJO, Rebeca (Org.). O ensino de história em questão. Cultura histórica, uso do passado. Rio de Janeiro: 2015, p. 201-222.

SONTAG, Susan. Doença como metáfora. Rio de Janeiro: Companhia de Bolso, 2007.

WALTON, Stuart. Uma história das emoções. Rio de Janeiro: Record, 2007.

Recebido em 21 de fevereiro de 2018 